\title{
Information Systems Executives: The Changing Role of New IS/IT Leaders
}

\author{
Petter Gottschalk \\ Norwegian School of Management \\ petter.gottschalk@bi.no
}

\begin{abstract}
Leadership in information systems (IS) and information technology (IT) has changed in fundamental ways over the past decade. While interest in the topic has increased in recent years, little empirical research on IS/IT leadership has been conducted. This study compares leadership roles, individual characteristics and position characteristics of newly appointed IS/IT executives (those who have been in their position for two years or less) with established IS/IT executives using a survey conducted in Norway. Survey results indicate that new leaders spend more time in the informational role and in the change-leader role than established leaders. New leaders have worked a shorter time in the organization and a shorter time in IS/IT than established leaders. New leaders have less responsibility for computer operations, communication networks and technical infrastructure than established leaders.
\end{abstract}

Keywords: IS/IT leadership; leadership roles; IS/IT executives; new leaders; established leaders.

\section{INTRODUCTION}

Information systems (IS) / information technology (IT) leadership has undergone fundamental changes over the past decade (Cross et al., 1997; CSC, 1996; Stephens et al., 1995). Despite increased interest in recent years (e.g., Armstrong and Sambamurthy, 1995; Brown et al., 1996; Earl and Feeny, 1994; Rockart et al., 1996), little empirical research on IS leadership has been conducted. Recommendations in the literature on how to succeed as an IT/IS manager typically lack empirical evidence (e.g., Baxter, 1997).

The Applegate and Elam (1992) study of newly appointed IS executives motivated this research. Their study defined a new senior IS executive as one who had been in the position for two years or less, and an established IS executive as one who had been in the position for more than two years. This research applied the same definitions.

\section{RESEARCH QUESTIONS}

The study addressed the following questions:

1. What are the main leadership roles of new IS executives?

Material published as part of this journal, either on-line or in print, is copyrighted by the publisher of Informing Science. Permission to make digital or paper copy of part or all of these works for personal or classroom use is granted without fee provided that the copies are not made or distributed for profit or commercial advantage AND that copies 1) bear this notice in full and 2) give the full citation on the first page. It is permissible to abstract these works so long as credit is given. To copy in all other cases or to republish or to post on a server or to redistribute to lists requires specific permission and payment of a fee. Contact Editor@inform.nu to request redistribution permission.
Do they differ from those of established IS executives?

2. What are the individual characteristics of new IS executives? Do they differ from those of established IS executives?

3. What are the characteristics of new IS executives' positions? Do they differ from those of established IS executives?

\section{LEADERSHIP ROLES}

Managers undertake activities to achieve the objectives of the organization. Mintzberg (1994) notes a number of different and sometimes conflicting views of the manager's role. He finds that it is a curiosity of the management literature that its best-known writers all seem to emphasise one particular part of the manager's job to the exclusion of the others. Together, perhaps, they cover all the parts, but even that does not describe the whole job of managing. Mintzberg's role typology is frequently used in studies of managerial work (e.g., Pinsonneault and Rivard, 1998).

Describing the manager's work has been an ongoing pursuit of researchers and practitioners. The manager's work is characterised by brevity, variety, fragmentation of tasks, a preference for action (as opposed to reflection), and a preference for oral communication over formal reports (Mintzberg, 1994). Managers in organizations are continuously confronted by an array of ambiguous data and vaguely felt stimuli that they must somehow order, explicate and imbue with meaning before they decide on how to respond (Kuvaas, 1998). Kotter (1999) identified two main roles for executives: agenda setting and network building. While agenda setting is concerned with figuring out what to do despite uncertainty and an enormous 


\section{IS Executives}

amount of potentially relevant information, network building is concerned with getting things done through a large and diverse group of people despite having little direct control over most of them.

A number of models describing the manager's work have been proposed including functional descriptions such as planning, organising, directing, controlling, co-ordinating, and innovating. Similarly, frameworks based on the methods used to accomplish these functions, for example, Mintzberg's role typology, have been proposed. According to Mintzberg (1990), the manager's job can be described in terms of various roles:

1. Informational Roles. By virtue of interpersonal contacts, both with subordinates and with a network of contacts, the manager emerges as the nerve centre of the organizational unit. The manager may not know everything but typically knows more than subordinates do. Processing information is a key part of the manager's job. As monitor, the manager is perpetually scanning the environment for information, interrogating liaison contacts and subordinates, and receiving unsolicited information, much of it as a result of the network of personal contacts. As a disseminator, the manager passes some privileged informa- tion directly to subordinates, who would otherwise have no access to it. As spokesperson, the manager sends some information to people outside the unit.

2. Decisional Roles. Information is not an end in itself; it is the basic input to decision making. The manager plays the major role in a unit's decision-making system. As its formal authority, only the manager can commit the unit to important new courses of action; and as its nerve centre, only the manager has full and current information to make the set of decisions that determines the unit's strategy. As entrepreneur, the manager seeks to improve the unit, to adapt it to changing conditions in the environment. As disturbance handler, the manager responds to pressures from situations. As resource allocater, the manager is responsible for deciding who will get what. As negotiator, the manager commits organizational resources in real time.

3. Interpersonal Roles. As figurehead, every manager must perform some ceremonial duties. As leader, managers are responsible for the work of the people of their unit. As liaison, the manager makes contacts outside the vertical chain of command.

1. Chief architect. The chief architect designs future possibilities for the business. The primary work of the chief architect is to design and evolve the IT infrastructure so that it will expand the range of future possibilities for the business, not define specific business outcomes. The infrastructure should provide not just today's technical services, such as networking, databases and desktop operating systems, but an increasing range of business-level services, such as workflow, portfolio management, scheduling, and specific business components or objects.

2. Change leader. The change leader orchestrates resources to achieve optimal implementation of the future. The essential role of the change leader is to orchestrate all those resources that will be needed to execute the change program. This includes providing new IT tools, but it also involves putting in place teams of people who can redesign roles, jobs and workflow, who can change beliefs about the company and the work people do, and who understand human nature and can develop incentive systems to coax people into new and different behaviours.

3. Product developer. The product developer helps define the company's place in the emerging digital economy. For example, a product developer might recognise the potential for performing key business processes (perhaps order fulfilment, purchasing or delivering customer support) over electronic linkages such as the Internet. The product developer must "sell" the idea to a business partner, and together they can set up and evaluate business experiments, which are initially operated out of IS. Whether the new methods are adopted or not, the company will learn from the experiments and so move closer to commercial success in emerging digital markets.

4. Technology provocateur. The technology provocateur embeds IT into the business strategy. The technology provocateur works with senior business executives to bring IT and realities of the IT marketplace to bear on the formation of strategy for the business. The technology provocateur is a senior business executive who understands both the business and IT at a deep enough level to integrate the two perspectives in discussions about the future course of the business. Technology provocateurs have a wealth of experience in IS disciplines, so they understand at a fundamental level the capabilities of IT and how IT impacts the business.

5. Coach. The coach teaches people to acquire the skillsets they will need for the future. Coaches have two basic responsibilities: teaching people how to learn, so that they can become self-sufficient, and providing team leaders with staff able to do the IT-related work of the business. A mechanism that assists both is the centre of excellence - a small group of people with a particular competence or skill, with a coach responsible for their growth and development. Coaches are solid practitioners of the competence that they will be coaching, but need not be the best at it in the company.

6. Chief operating strategist. The chief operating strategist invents the future with senior management. The chief operating strategist is the top IS executive who is focused on the future agenda of the IS organisation. The strategist has parallel responsibilities related to helping the business design the future, and then delivering it. The most important, and least understood, parts of the role have to do with the interpretation of new technologies and the IT marketplace, and the bringing of this understanding into the development of the digital business strategy for the organisation. 


\section{IS/IT LEADERSHIP ROLES}

Changes in both information technology and competition continue to change the role of the information systems executive. Computer Sciences Corporation (CSC, 1996) has suggested six new IS leadership roles that are required to execute IS's future agenda: chief architect, change leader, product developer, technology provocateur, coach and chief operating strategist. These roles are described in Table 1. Although the CSC consultancy firm produced these roles without using any scientific approach, they seem very well tailored for scientific investigation into IS leadership roles. People who fill these roles do not necessarily head up new departments or processes, but they exert influence and provide leadership across the organizational structure.

\section{STUDY METHODOLOGY}

Data were collected through a survey in Norway. In Norway, IS/IT leadership roles are frequently debated. The top ranked IS/IT leader or CIO as defined by Stephens et al. (1992) is typically called "IT-direktør" (IT director), "IT-sjef" (IT-manager) or "IS-leder" (IS-leader) in Norway. The survey sample consisted of 168 private and public member firms of the Norwegian Computing Society (NCS). This sample is biased towards organizations interested in IS/IT issues in general. The informants in this research were IS/IT managers who reported their own perceptions of roles and possible explanations of roles.

For each of Mintzberg's (1994) three leadership roles, respon-

\begin{tabular}{|lr|}
\hline Primary Activity & Percent \\
Manufacturing & 39 \\
Service & 21 \\
Public administration & 21 \\
Trade & 12 \\
Finance & 7 \\
TOTAL & 100 \\
\hline
\end{tabular}

Table 2: Sample Breakdown by Industry

dents were asked to indicate how much time they spent in each role. An extent response of one indicated that they spent little time in that role, while an extent response of six indicated that a great deal of time is spent in that role.

For each of CSC's (1996) six leadership roles, respondents were asked to indicate the extent to which that role characterizes their job. For example, an extent response of one for chief architect implies that this role does not characterize at all the job, while an extent response of six indicates that the chief architect characterizes the job really well.

Variables in the research model were operationalized by both single item measures and multiple item measures. For example, a ten-item scale measured responsibility, which is one of

\begin{tabular}{|lccc|}
\hline Leadership role & $\begin{array}{c}\text { New } \\
\text { IS/IT leaders }\end{array}$ & $\begin{array}{c}\text { Established } \\
\text { IS/IT leaders }\end{array}$ & $\begin{array}{c}\text { t-statistic for } \\
\text { difference }\end{array}$ \\
Informational Role & 4.35 & 3.98 & $1.547^{*}$ \\
Decisional Role & 4.43 & 4.58 & -.793 \\
Interpersonal Role & 4.38 & 4.42 & -.207 \\
Chief architect & 4.27 & 4.28 & -.027 \\
Change leader & 4.61 & 4.24 & $1.490^{*}$ \\
Product developer & 3.27 & 3.57 & -1.252 \\
Technology provocateur & 4.29 & 4.26 & .140 \\
Coach & 4.12 & 4.22 & -.487 \\
Chief operating strategist & 4.27 & 4.31 & -.159 \\
\hline Note: ${ }^{*}$ if $p<.10,{ }^{* *}$ if $p<.05,{ }^{* * *}$ if $p<.01$ & & \\
\hline
\end{tabular}

Table 3: Leadership Roles 


\section{IS Executives}

the position characteristics. The item questions were concerned with responsibility for information systems, computer operations, communication networks, strategic IS/IT planning, bridging IS/IT and business strategy, benefits realization, information architecture, technical infrastructure, IS/IT budget, and IS/IT personnel (Applegate and Elam, 1992; Boynton et al., 1992; Cross et al., 1997; CSC, 1996; Earl and Feeny, 1994; Rockart et al., 1996; Stephens et al., 1995).

\section{RESULTS}

Of the 168 mailed questionnaires, 101 were returned, providing a response rate of $60 \%$. The sample included organizations from a broad range of industries, as listed in Table 2.

Out of 101 responses, 41 IS executives had been in the current position for two years or less, while 60 IS executives had been in the current position for five or more years. These two groups are used in the following and labeled new and established respectively.

While Mintzberg (1994) defined three general leadership roles, CSC (1996) defined six IS/IT leadership roles. A Likert scale from 1 (low/little) to 6 (high/great) was used to measure the extent of each role as listed in Table 3.

Substantial differences between new and established IS/IT leaders were found in the informational role and the change leader role. While the change leader role is the highest scoring role among new IS/IT leaders, it is a relatively modest role among established IS/IT leaders. According to CSC (1996), a change leader orchestrates resources to achieve optimal implementation of the future. The essential role of the change leader is to orchestrate all those resources that will be needed to execute the change program. This includes providing new IT tools, but it also involves putting in place teams of people who can redesign roles, jobs and workflow, who can change beliefs about the company and the work people do, and who understand human nature and can develop incentive systems to coax people into new and different behaviors.

Information on individual characteristics of IS/IT leaders was collected through the survey and listed in Table 4 . New IS/IT leaders have worked significantly fewer years in the organization and in IS/IT than established IS/IT leaders. Concerning characteristics such as education level, personal technology use and relationship with chief executive, new and established IS/IT leaders report similar characteristics.

IS leaders were classified as internal hires if they had been with the company for more than five years at the time they had assumed the IS leadership position. Individuals were classified as external hires if they had been with the company for five years or less. Five years was chosen as the cutoff because individuals are typically considered to be part of the corporate establishment after five years of employment (Applegate and Elam, 1992). The results of this survey show that internal hires have increased.

Information on characteristics of the IS/IT leadership position was collected through the survey and listed in Table 5.

\begin{tabular}{|lccc|}
\hline Characteristics & $\begin{array}{c}\text { New } \\
\text { IS/IT leaders }\end{array}$ & $\begin{array}{c}\text { Established } \\
\text { IS/IT leaders }\end{array}$ & $\begin{array}{c}\text { t-statistic for } \\
\text { difference }\end{array}$ \\
Years worked in the organization & 6.42 & 10.81 & $-2.922^{* * *}$ \\
Years worked in IS/IT & 12.55 & 17.15 & $-2.910^{* * *}$ \\
Years worked in current position & 1.36 & 6.01 & $-8.077^{\star \star *}$ \\
Years of higher education & 4.47 & 4.52 & -.093 \\
Internal hires & $44 \%$ & $30 \%$ & - \\
Extent of IS/IT use & 5.54 & 5.69 & -1.106 \\
Relationship with chief executive & 1.59 & 1.59 & -.097 \\
\hline Note: * if $\mathrm{p}<10$, ** if $\mathrm{p}<05, * * *$ if $\mathrm{p}<01$ & & &
\end{tabular}

Table 4: Individual Characteristics 


\begin{tabular}{|lccc|}
\hline Characteristics & $\begin{array}{c}\text { New } \\
\text { IS/IT leaders }\end{array}$ & $\begin{array}{c}\text { Established } \\
\text { IS/IT leaders }\end{array}$ & $\begin{array}{c}\text { t-statistic for } \\
\text { difference }\end{array}$ \\
Persons reporting to leader & 18.05 & 20.93 & -.350 \\
Reporting level & 1.05 & 0.82 & $1.508^{*}$ \\
Responsibility for information systems & 4.73 & 4.90 & -.634 \\
Responsibility for computer operations & 4.29 & 5.10 & $-2.355^{\star *}$ \\
Responsibility for communication networks & 4.32 & 5.03 & $-2.026^{\star *}$ \\
Responsibility for strategic IS/IT planning & 5.34 & 5.15 & 0.976 \\
Responsibility for bridging strategy & 4.80 & 4.52 & 1.122 \\
Responsibility for benefits realization & 3.61 & 3.44 & 0.597 \\
Responsibility for information architecture & 4.37 & 4.66 & -1.113 \\
Responsibility for technical infrastructure & 4.41 & 5.20 & $-2.835^{\star * *}$ \\
Responsibility for IS/IT budget & 5.07 & 5.44 & $-1.611^{*}$ \\
Responsibility for IS/IT personnel & 4.76 & 5.41 & $-2.241^{* *}$ \\
\hline
\end{tabular}

Note: ${ }^{*}$ if $p<.10,{ }^{* *}$ if $p<.05,{ }^{* *}$ if $p<.01$

Table 5: Characteristics of Position

Reporting level was measured as the number of management levels between the IS/IT executive and the chief executive. It may seem surprising that new IS/IT leaders are lower in the hierarchy than established IS/IT leaders. This finding differs from earlier research where Applegate and Elam (1992) found that an increasing number of new IS executives reported directly to the CEO. It is interesting to speculate what might lie behind this finding. One explanation might be the decentralization and/or outsourcing of IT functions without central coordination in Norwegian organizations.

Five dimensions of responsibility show some differences between new and established leaders. Typically, strategic
IS/IT planning, bridging IS/IT planning and benefits realization represent strategic responsibilities. These responsibilities have a higher score among new IS/IT leaders, but the differences are not statistically significant. Typically, computer operations and communication networks represent operating responsibilities. These responsibilities have a significantly lower score among new IS/IT leaders.

The analyses so far have treated experience (years worked in current position) as a dichotomous variable. When experience is treated as a continuous measure in regression analyses, results as listed in Table 6 emerge. 


\begin{tabular}{|c|c|c|c|c|}
\hline Dependent variable & $\begin{array}{l}\text { Adjusted R- } \\
\text { square }\end{array}$ & $\begin{array}{l}\text { Regression } \\
\text { F-statistic }\end{array}$ & $\begin{array}{c}\text { Beta } \\
\text { coefficient }\end{array}$ & $\begin{array}{c}\text { Coefficient } \\
\text { t-statistic }\end{array}$ \\
\hline Informational role & .070 & 1.723 & -.132 & -1.313 \\
\hline Decisional role & .001 & 1.090 & .105 & 1.044 \\
\hline Interpersonal role & .006 & 1.603 & .127 & 1.266 \\
\hline Chief architect & -.010 & 0.064 & .026 & 0.253 \\
\hline Change leader & .041 & $5.230^{* *}$ & -.226 & $-2.287^{\star *}$ \\
\hline Product developer & .002 & 1.226 & .112 & 1.107 \\
\hline Technology provocateur & .004 & 1.437 & -.121 & -1.199 \\
\hline Coach & -.008 & 0.234 & -.049 & -0.484 \\
\hline Chief operating strategist & -.010 & 0.076 & -.028 & -0.276 \\
\hline Years worked in the organization & .270 & $37.542^{* * *}$ & .526 & $6.127^{\star * *}$ \\
\hline Years worked in IS/IT & .167 & $20.583^{\star * *}$ & .418 & $4.537^{\star \star *}$ \\
\hline Years of higher education & .001 & 1.105 & -.107 & -1.051 \\
\hline Internal hires & -.006 & 0.380 & .062 & 0.616 \\
\hline Extent of IS/IT use & -.010 & 0.006 & -.008 & -0.079 \\
\hline Relationship with chief executive & -.010 & 0.000 & -.001 & -0.012 \\
\hline Persons reporting to leader & -.010 & 0.086 & -.030 & -0.293 \\
\hline Reporting level & -.008 & 0.179 & -.043 & -0.423 \\
\hline Responsibility for information systems & -.001 & 0.944 & .098 & 0.972 \\
\hline Responsibility for computer operations & -.002 & 0.827 & .091 & 0.909 \\
\hline Responsibility for communication networks & .012 & 2.246 & .150 & 1.499 \\
\hline Responsibility for strategic IS/IT planning & .013 & 2.301 & -.151 & -1.517 \\
\hline Responsibility for bridging IS/IT and business strategy & .028 & $3.894^{*}$ & -.195 & $-1.973^{*}$ \\
\hline Responsibility for benefits realization & .006 & 1.570 & -.126 & -1.253 \\
\hline Responsibility for information architecture & -.010 & 0.042 & .021 & 0.205 \\
\hline Responsibility for technical infrastructure & .015 & 2.492 & .157 & 1.579 \\
\hline Responsibility for IS/IT budget & .008 & 1.792 & .134 & 1.339 \\
\hline Responsibility for IS/IT personnel & .046 & $5.818^{\star *}$ & .237 & $2.412^{\star *}$ \\
\hline
\end{tabular}

Note: * if $p<.10,{ }^{* *}$ if $p<.05,{ }^{* * *}$ if $p<.01$

Table 6: Regression Analysis using Experience as Predictor

Regression analysis confirms the decreasing change leader role as the years in current position increase. For other predicted variables, regression analysis provides slightly different results. For example, while decreasing responsibility for computer operations among new leaders was not confirmed, there is a significant positive relationship between the number of years in current position and the extent to which the leader has responsibility for IS/IT personnel.

\section{COMPARISON OF SURVEY RESULTS}

Among all the 101 respondents, 44 percent reported to the managing director (CEO), while 23 percent reported to the financial director, and 33 percent reported to others (technical director, staff director, or other). As illustrated in Table 7, these results are in line with recent previous studies.

The conducted survey collected data on the three roles defined by Mintzberg (1990). Stephens found that the five CIOs that she studied spent most of their time in the decisional roles $(60 \%)$, less of their time in the informational roles $(36 \%)$ and 
very little time in the interpersonal roles (4\%). This research suggests that Norwegian CIOs, on a scale from 1 (little extent) to 6 (great extent), have the same decision roles ranked on top (4.5), but they spend much more time on interpersonal roles (4.4) and informational roles (4.1) than the CIOs in the Stephens study.

In this survey, respondents had been in the current position for the last 4.1 years. This is slightly less than the results obtained by CSC (1997) who found that the average reported tenure of a company's senior IS professional was 4.7 years world wide, ranging from 5.0 years in North America, 4.9 years in Europe to 4.0 years in Asia Pacific.

\begin{tabular}{|lcccc|}
\hline Reporting Relationship of Respondents & $\begin{array}{c}\text { Applegate } \\
\text { \& Elam } \\
(1992)\end{array}$ & $\begin{array}{c}\text { CSC } \\
(\mathbf{1 9 9 7 )}\end{array}$ & $\begin{array}{c}\text { Gott- } \\
\text { schalk } \\
(\mathbf{1 9 9 8 )}\end{array}$ & $\begin{array}{c}\text { This study } \\
\text { (1999) }\end{array}$ \\
Reports directly to managing director (CEO) & $27 \%$ & $43 \%$ & $48 \%$ & $44 \%$ \\
Reports to financial director (CFO) & $44 \%$ & $32 \%$ & $21 \%$ & $23 \%$ \\
Reports to other officer & $29 \%$ & $25 \%$ & $31 \%$ & $33 \%$ \\
\hline
\end{tabular}

Table 7: Information Systems Executive Reporting Relationship

Seven years ago, Boynton et al. (1992) posed the question: Whose responsibility is IT management? They claimed that line managers were increasingly assuming responsibility for planning, building, and running information systems that affect their operations. In this perspective, it is interesting to study results from this survey. For example, realization of benefits is not a large responsibility of IS leaders as illustrated in Table 5. A possible explanation is that line managers assume this responsibility.

Applegate and Elam (1992) found that 53\% of new IS leaders were internal hires, while $94 \%$ of established IS leaders were internal hires. In this survey, $44 \%$ and $45 \%$ respectively were internal hires. The fraction of internal hires in this survey was lower, and there was no difference between new and established IS leaders.

\section{IMPLICATIONS AND FUTURE RESEARCH}

The CIO function is a continuously evolving role (Stephens, 1993). The present research provides a snapshot in this progression. Identifying these trends in information systems leadership has implications for both research and practice. First, educators can use this information to develop management programs. Second, these roles and trends represent important guidelines for practicing CIOs. The senior IS execu- tives must be able to bring both a business and IT perspective to the position. This is often called the hybrid manager because the manager must be able to work as comfortably in the business as in the technical arena (Baxter, 1997). More definitive role expectations could also aid in career planning (Applegate and Elam, 1992). Finally, clarifying the CIO role also has implications for office technology design and use. Studies continue to show the executives' preference toward verbal communications (Stephens, 1993). These studies also point to relatively limited use of the technologies that these managers purvey. One possibility is that this limited technology use is due in part to limitations in the technologies themselves. Identifying these limitations could improve executive acceptance of these systems. However, the survey data do not

show us what technology the CIOs use.

Table 7 compares four studies that include samples from very different organizational and cultural backgrounds. IS leadership roles in the Norwegian culture may be different from other studies done in the US and UK or around the globe. For example, Norwegian organizations tend to be much smaller than surveyed organizations in the US, and hierarchies in Norway tend to be flatter than in most other countries. Such aspects can lead to implications for management practice and future research. According to the Scandinavian research on information systems development, Scandinavia has high living standards and educational levels, an advanced technology infrastructure, an open community and key innovative leaders (Boland, 1999). This research tradition seems different from research in other countries such as the UK with control structures (Towell et al., 1998) and Mexico with economic development (Mejias et al., 1999), which may imply different IS leadership roles. In future research, eight cultural dimensions can be investigated: power distance, uncertainty avoidance, individualism, masculinity, time orientation, monocrony and polychrony, context, and polymorphic and monomorphic (Hasan and Ditsa, 1999).

Future research should not take the six leadership roles from CSC (1996) for granted. Analysis of the leadership roles has to be performed. Many leadership actions are multifunctional and include several of these role attributes. A more critical 


\section{IS Executives}

stance towards preconditions such as leadership roles should be applied.

The current study documents the assessment of IS/IT executives on a leadership survey. The intention was to be primarily descriptive, e.g., the paper offers an empirical contribution in the form of descriptions of how IS/IT leaders currently score on different leadership measures. Future research should explore theoretical contribution and develop empirically testable hypotheses. For example, it is suggested that IS/IT leadership roles have changed, but the current paper offers no theoretical reasons for believing this to be the case. Such theoretical reasons might allow the researcher to predict more change in the IS/IT leadership roles in some organizations possessing certain characteristics than in others.

From a methodological standpoint, self-report of leadership roles and activities is not a strong approach to assessing leadership. Preferable would be to (additionally) use subordinates or superiors as informants, to insure against incumbents simply reporting what they think they are supposed to be doing, or what they would like to be doing, rather than what they are doing.

The use of Mintzberg's (1990) role definitions in three general groupings is questionable, although undoable for this particular survey. For further research it is suggested that the use of Mintzberg's (1990) precisely defined eight roles plus the differentiation of internal versus external role (leader of the group and liaison with external groups) is probably much more meaningful than a generalized grouping of these roles. The roles themselves may overlap, and the call is often of "best fit". These specific roles link more closely to the CSC (1996) set as well. If future surveys use the more precisely defined roles, a comparison with those rather than the groupings can be very interesting.

\section{CONCLUSIONS}

The empirical analysis indicated that operational responsibilities are decreasing among IS/IT leaders. They spend much of their time as change leaders.

The data provided in this research will hopefully stimulate similar research in other nations and regions. Just like key IS management issues research has enabled global comparisons (Watson et al., 1997), future IS leadership research may gain from global comparisons as indicated in the section on survey comparisons. Practicing IS/IT leaders will gain from this research by balancing leadership roles according to individual characteristics, organizational characteristics and stages of growth.

\section{REFERENCES}

Andrews, P. \& Carlson, T. (1997). The CIO IS The CEO Of The Future. CIO Conference, Naples, Florida,

http://www.cio.com/conferences/eds/sld018.htm.

Applegate, L.M. \& Elam, J.J. (1992). New Information Systems Leaders: A Changing Role in a Changing World. MIS Quarterly, 16 (4), 469-490.

Applegate, L.M.; McFarlan, F.W. \& McKenney, J.M. (1996). Corporate Information Systems Management, USA: Irwin, Chicago.

Armstrong, C.P. \& Sambamurthy, V. (1995). Creating business value through information technology: The effects of chief information officer and top management team characteristics. Proceedings of the International Conference on Information Systems, Netherlands.

Baxter, S. (1997). The Role of the IT/IS Manager, Financial Times Management Briefings, UK: Pitman Publishing.

Beyer, J.M., Chattopadhyay, P., George, E., Glick, W.H. \& Pugliese, D. (1997). The selective perception of managers revisited. Academy of Management Journal, vol. 40 (3), pp. 716-737.

Boland, R.J. (1999). Some Sources of the Unity in Plurality of Scandinavian Research on Information Systems Development, Scandinavian Journal of Information Systems, vol. 10 (1\&2), pp. 187-192.

Boyle, R.D. (1994). Critical success factors for establishing and maintaining the position of CIO. Information Strategy: The Executive's Journal, 10, 29-38.

Boynton, A.C., Jacobs, G.C. \& Zmud, R.W. (1992). Whose responsibility is IT management? Sloan Management Review, 33 (4), 32-38.

Broadbent, M., Butler, C. \& Hansell, A. (1994). Business and technology agenda for information systems executives. International Journal of Information Management, 14 (6), 411-423.

Brown, C.V., McLean, E.R. \& Straub, D.W. (1996). Partnering Roles of the IS Executive, Information Systems Management, Spring.

Cross, J., Earl, M.J. \& Sampler, J.L. (1997). Transformation of the IT function at British Petroleum. MIS Quarterly, 21 (4), 401-423.

CSC (1996). New IS leaders, CSC Index Research, UK: London.

CSC (1997). Critical Issues of Information Systems Management - 10th Annual Survey, Computer Sciences Corporation, USA: El Segundo, California.

Earl, M.J. \& Feeny, D.F. (1994). Is your CIO adding value? Sloan Management Review, 35 (3), 11-20.

Feeny, D.F., Edwards, B.R. \& Simpson, K.M. (1992). Understanding the CEO/CIO Relationship. MIS Quarterly, December, 435-448.

Gottschalk, P. (1998). Content Characteristics of Formal Information Technology Strategy as Implementation Predictors, Tano Aschehoug Publishing, Norway: Oslo. 
Hasan, H. \& Ditsa. G. (1999). The Impact of Culture on the Adoption of IT: An Interpretive Study, Journal of Global Information Management, vol. 7 (1), pp. 5-15.

Heckman, R. (1998). Planning to Solve the "Skills Problem" in the Virtual Information Management Organisation, International Journal of Information Management, vol. 18 (1), pp. 3-16.

Henderson, J. \& Venkatraman, N. (1992). Strategic Alignment: A Model for Organisational Transformation through IT, in Kochan, T.A. and M. Useem, Transforming Organisations, UK: Oxford University Press.

Jones, M.C., Taylor, G.S. \& Spencer, B.A. (1995). The CEO/CIO relationship revisited: An empirical assessment of satisfaction with IS. Information \& Management, 29 (3), 123-130.

Jordan, E. (1993). Executive information systems for the chief information officer. International Journal of Information Management, 13 (4), 249-259

Khandelwal, V.K. \& Ferguson, J.R. (1999). Critical Success Factors (CSFs) and the Growth of IT in Selected Geographic Regions, Proceedings of the 32nd Hawaii International Conference on Systems Sciences (HICSS-32), January 5-8, USA: Maui.

King, J.L. \& Kraemar, K.L. (1984). Evolution and Organisational Information Systems: An Assessment of Nolan's Stage Model, Communications of the ACM, vol. 17 (5), pp. 466-475.

Kotter, J.P. (1999). What effective general managers really do, Harvard Business Review, March-April, pp. 145-158.

Kuvaas, B. (1998). Strategic issue diagnosis: The roles of organisational scanning, information processing structure of top management teams, and managers' cognitive complexity, Unpublished doctoral dissertation, Norway: Norwegian School of Economics and Business Administration.

Mejias, R.J., Palmer, J.W. \& Harvey, M.G. (1999). Emerging Technologies, IT Infrastructure, and Economic Development in Mexico, Journal of Global Information Technology Management (JGITM), vol. 2 (1), pp. 31-54.

Mintzberg, H. (1990). The Manager's Job: Folklore and Fact. Harvard Business Review, March-April.

Mintzberg, H. (1994). Rounding out the manager's job. Sloan Management Review, 36 (1), 11-26.
Moore, G.C. \& Benbasat, I. (1991). Development of an Instrument to Measure the Perceptions of Adopting an Information Technology Innovation, Information Systems Research, vol. 2 (3), pp. 192-222.

Nolan, R.L. (1973). Managing the Computer Resource: A Stage Hypothesis. Communications of the ACM, vol. 16 (7), pp. 399-405.

Nolan, R.L. (1979). Managing the crisis in data processing. Harvard Business Review, March-April, pp. 115-126.

Peppard, J. (1999). Bridging the gap between IT organisation and the rest of the business: plotting a route. Proceedings of the 7th European Conference on Information Systems (ECIS), June 23-25, Copenhagen, Denmark, vol. II, pp. 542-558.

Pinsonneault, A. \& Rivard, S. (1998). Information Technology and the Nature of Managerial Work: From the Productivity Paradox to the Icarus Paradox?, MIS Quarterly, September, 287-311.

Rockart, J.F., Earl, M.J. \& Ross, J.W. (1996). Eight Imperatives for the New IT Organisation. Sloan Management Review, 38 (1), 43-55.

Stephens, C.S. (1993). Five CIO's At Work: Folklore and Facts Revisited. Journal of Systems Management, 44 (3), 34-40.

Stephens, C.S., Ledbetter, W.N., Mitra, A. \& Ford, F.N. (1992). Executive or Functional Manager? The Nature of the CIO's Job. MIS Quarterly, 16 (4), 449-467.

Stephens, C.S. \& Loughman, T. (1994). The CIO's chief concern: Communication. Information \& Management, 27 (2), 129-137.

Stephens, C.S., Mitra, A., Ford, F.N. \& Ledbetter, W.N. (1995). The CIO's Dilemma: Participating in Strategic Planning. Information Strategy, 11 (3), 13-17.

Towell, R.E, McFadden, K.L. \& Lauer, J. (1998). ISO 9000 Certification in the U.K.: A Study of the Role Played by the Information Systems Organisation, Journal of Global Information Technology Management (JGITM), vol. 1 (4), pp. 3-16.

Watson, R.T. (1990). Influences on the IS manager's perceptions of key issues: Information scanning and the relationship with the CEO. MIS Quarterly, 14 (2), 217-231.

Watson, R.T., Kelly, G.G., Galliers, R.D. \& Brancheau, J.C. (1997) Key issues in information systems management: An international perspective. Journal of Management Information Systems, 13 (4), 91-115. 